\title{
An Analysis of the Representation of Practical Work in Secondary Chemistry Textbooks from Different Chinese Communities
}

\author{
Xiaoge Chen*, Ingo Eilks \\ Department of Biology and Chemistry, Institute for Science Education, University of Bremen, Bremen, Germany \\ *Corresponding Author: chen@uni-bremen.de
}

\section{ABSTRACT}

This study analyzed representations of practical work in $10^{\text {th }}$ grade chemistry textbooks and associated experimental workbooks from different Chinese communities. In the field of textbook research, science education textbooks research is unbalanced between regions. In the case of chemistry textbooks analysis within the Chinese context, textbook studies are even more limited. To close the gap, this paper contributes to the current body of knowledge of how practical work in secondary chemistry education is suggested to be applied in Chinese educational contexts. A total of 508 representations related to practical work were identified in seven sets of textbooks from Mainland China, Taiwan, and the Chinese sector in Malaysia. The goal was to gain basic insights into the features associated with suggested approaches to practical work in the textbooks. Our focus was on the suggested type of learning, intended learning outcomes, inquiry level, and aspects of students' engagement with practical work. The results indicated a prevalence of prescribed experiments. This preference was then followed by illustrations of facts and laboratory operation processes. Only a limited amount of scientific inquires with at least some amount of openness were located among the list of preferred items. The intended learning outcomes mainly aim at learning facts. Most textbooks suggest using a structured learning approach. Some suggestions of inquiry-based learning using either guided or open inquiry approaches do occur, but they are relatively limited in the textbooks and do not appear frequently. The results of this study may provide a view for science textbook editors and curriculum designers to identify areas for further improvement.

KEY WORDS: chemistry education; textbook analysis; practical work/laboratory

\section{INTRODUCTION}

$\mathbf{P}$ erforming science is about gathering evidence from nature (Watson et al., 2004), or, more specifically as described by Millar (2004), science is an endeavor to gain an evidence-based body of knowledge about the natural world. Ways to generate evidence from nature include observations of natural phenomena, both in nature or in a laboratory context. That is why observations in nature and practical work have achieved their distinctive role in science education. They have maintained this central role until today (Hofstein, 2017).

Most educational standards and traditions in science education state the importance of practical work for the teaching and learning of science (Hofstein, 2017). We use the term practical work in a broader sense, which includes many other notions such as laboratory work, laboratory activity, investigation, inquiry, and experimentation. In this paper, it refers to any kind of teacher or student interaction either with equipment or materials to produce or observe phenomena, from which students achieve a better understanding of the natural world (Hofstein \& Lunetta, 2004).

As stated by Millar et al. (1999), practical work can help in communicating information and ideas about the natural world to students. In the classroom, there are basically two sources which lead students into practical work, i.e., teachers and textbooks. The focus of this paper is on textbooks, because textbooks are teaching aids where students may obtain knowledge (Devetak \& Vogrinc, 2013). Furthermore, textbooks represent the intended curriculum, which teachers adapt and re-structure towards implemented teaching practices (Chen et al., 2019). Scientific textbooks play an important role in science education in general (Aldahmash et al., 2016), and in chemistry education in particular (Rusek \& Vojír, 2019). The importance of quality textbooks is especially high in countries where teaching tends to center around a selected textbook, such as in the People's Republic of China (Wang et al., 2015). There is a growing body of literature emphasizing the important role of critically analyzing textbooks (Clement, 2008). It is suggested that textbooks aim at defining school subjects (Devetak \& Vogrinc, 2013), representing the intended curriculum (Khaddoor et al., 2017; Aldahmash et al., 2016; Tamir \& Pilar-Garcia, 1992), promoting conceptual learning and helping in achieving scientific literacy (Upahi \& Ramnarain, 2019; Wei \& Chen, 2017), and presenting proper content for guiding teaching and learning (Kim \& Kim, 2013; Abd-El-Khalick et al., 2008; Stern \& Roseman, 2004). In this study, we focus on how textbooks from different Chinese communities in Mainland China, Taiwan, and the Chinese 
sector in Malaysia, introduce and represent practical work in chemistry education. A careful look was given to the suggested type of learning, the intended learning outcomes, the inquiry level, and students' engagement with practical work.

\section{THEORETICAL FRAMEWORK}

Practical work in the laboratory or in nature is widely (Katchevich et al., 2013; Abrahams \& Reiss, 2012; Jones et al, 2000; Millar et al., 1999) suggested as a tool to provide students with opportunities to experience the natural world for the sake of learning (Kim \& Song, 2006). This is also the case when it comes to helping students develop links between their observations and ideas (Abrahams \& Millar, 2008). In the current study, we apply the term "practical work" to all intended or represented hands-on processes, which help with a better understanding of evidence-based science performed inside and outside the laboratory. It covers any activity or associated reference where students can personally see or interact with materials and equipment to observe and understand the natural world. More specifically, the term refers to what students do or potentially can do, rather than to the location where the learning may take place. So practical work in our study concerns:

a. Any suggested experimental activities in class,

b. All suggested scientific investigations either in or out of the laboratory, and

c. Relevant pictures or sketches of experiments which potentially can be performed in the laboratory or beyond.

According to Katchevich et al. (2013), practical work builds a bridge between science and the learner by actively performing science. Practical work is seen as an integral part of science education in schools since it supports learning and is popular among students (Jones et al., 2000). Such work has the potential to promote higher-order cognitive skills if it is structured properly. It also provides chances for collaboration, deliberation, and communication with peers (Katchevich et al., 2013). Hofstein and Lunetta (1982) have suggested, based on their review of research, that practical work can also be considered as an effective teaching medium for achieving many of the stated goals of science education. They point out that practical work can facilitate students' learning and development and that it should play an important role in the achievement of the goals of science education. Practical work enables science teachers to facilitate both student learning and development to gain an understanding of what science is.

Practical work can encompass purposeful observations or scientific inquires by manipulating equipment and materials (Lederman \& Lederman, 2012). Such work is driven by questions, predictions, observations, analyses, and interpretations. The positive role of practical work for science learning is, however, not self-evident (Hofstein, 2017). Watson et al. (2004) suggested that students' discussions and decisionmaking processes in scientific inquiry often lag behind, if no clear emphasis is placed on a procedural understanding of scientific inquiry, instead of merely assessing individual practical skills and processes. Kim and Song (2006) promoted the use of more effective ways to organize practical work to promote students' thinking and to develop their argumentation abilities, such as the critical "peer review" of reports and arguments. The "thinking" part, for example, the negotiation of meaning in practical work, should, therefore, be emphasized more than the "doing" part. This resonates with work published by Newton et al. (1999).

In 2008, Abrahams and Millar described that teachers put greater emphasis on the interpretation of scientific content, instead of student inquiry, and practical tasks were seen to be deficient in helping students to make these links. Hofstein (2017) also pleaded recently for a deeper reflection on practical work, since the implementation of practical work seems not to have changed much over the past years. His arguments call for paying more attention to higher-order thinking skills and for starting new developments in laboratory teaching strategies and in teacher professional development. This call includes a rethinking of the goals of learning in and from practical work, including how it is presented to students.

Today, the most popular strategy suggested for practical work in science education is an inquiry. Inquiry-based practical work asks students to think of problems, formulate hypotheses, design experiments, gather data, and draw conclusions from scientific phenomena (Hofstein, 2017). There are, however, different levels of inquiry with respect to learners' mind-on involvement. A common typology of inquiry-based science education is related to the degree that students can influence scientific investigation. Banchi and Bell (2008) discussed four levels of inquiry-based learning in science education: Confirmatory, structured, guided, and open inquiry. The higher levels are believed to challenge students' thinking more and allow them to better construct meaning from a scientific investigation (Table 1).

In the practice of science, teaching factors such as time, equipment, and goals come into play, aside the textbook, when practical work is introduced. They determine whether teachers will choose guided or open inquiry or whether they will simply demonstrate an experiment to illustrate a scientific fact for their learners. Although there is a growing body of literature emphasizing the important role of textbooks in science teaching (for example Devetak \& Vogrinc, 2013) and various facets of learning were analyzed with reference to textbooks (Upahi \&

Table 1: Categorization of inquiry-based level (Banchi and Bell, 2008)

\begin{tabular}{lllll}
\hline Category & Inquiry level & Question & Method & Answer \\
\hline 1 & $\begin{array}{l}\text { Confirmatory } \\
\text { learning }\end{array}$ & Given & Given & Given \\
2 & $\begin{array}{l}\text { Structured } \\
\text { inquiry }\end{array}$ & Given & Given & Open \\
3 & Guided inquiry & Given & Open & Open \\
4 & Open inquiry & Open & Open & Open \\
\hline
\end{tabular}


Ramnarain, 2019; Khaddoor et al., 2017; Wei \& Chen, 2017; Aldahmash et al., 2016; Abd-El-Khalick et al., 2008; Stern \& Roseman, 2004; Tamir \& Pilar-Garcia, 1992), not much is known about how practical work is presented in secondary chemistry textbooks, especially in the context of secondary chemistry education in Chinese communities. This is why the current study focuses on how textbooks from different Chinese communities present practical work in chemistry education.

\section{SAMPLE}

The sample consists of seven sets of $10^{\text {th }}$ grade (students aged about 15 years old) secondary chemistry textbooks and the accompanying experimental workbooks from Mainland China, Taiwan, and the Chinese sector in Malaysia.

In People's Republic of China, there have been two major rounds of curriculum reforms over the past 20 years. In 2003, new national Upper Secondary School Chemistry Curriculum Standards were released by the Ministry of Education (Ministry of Education, 2003), and corresponding textbooks were reviewed and published (Wang, 2010). The latest round of standards was released in 2017 and was

\begin{tabular}{l}
\hline Table 2: Basic overview of features of practical work \\
(adapted from Millar et al., 1999) \\
\hline Practical work concerns \\
\hline C1: Type of learning \\
C1.1: Operating a given experiment \\
C1.2: Picture/sketch illustrations \\
C1.3: Picture/sketch illustration on a laboratory technique \\
C1.4: Scientific investigation with an open approach \\
C2: Intended learning outcomes \\
C2.1: Identify objects and learn a laboratory technique \\
C2.2: Learn fact (s) \\
C2.3: Learn concept \\
C2.4: Learn a relationship \\
C2.5: Learn a theory/model with reference to the sub-microscopic level \\
C3: Inquiry level of practical work \\
C3.1: Confirmatory learning without hypothesis \\
C3.2: Confirmatory inquiry learning \\
C3.3: Structured inquiry learning \\
C3.4: Guided inquiry learning \\
C3.5: Open inquiry learning \\
C4: Students' engagement \\
C4.1: Context \\
C4.2: Performance \\
C4.3: Application \\
\hline
\end{tabular}

meant to be implemented officially in the fall semester of 2018 (Ministry of Education, 2017). Since the textbooks corresponding to the newest 2017 standards are still under revision, the Ministry of Education has asked upper secondary schools to continue using the textbooks based on the 2003 standards (Ministry of Education, 2018). For this study, we chose three widely-used $10^{\text {th }}$ grade chemistry textbooks and their workbooks, which were suggested by the Ministry of Education. These textbooks are published by People's Education Press (further named CN1), Shandong Science and Technology Press (CN2), and Jiangsu Education Press (CN3) (Appendix 1). As one of the most developed cities in China, Shanghai is allowed to operate education under its own standards and choose its own textbooks. Textbooks for Shanghai are edited under the review of the Shanghai Primary and Secondary Curriculum and Teaching Materials Reform Commission (Sun et al., 2016). In this study, we chose the chemistry textbooks from Shanghai Scientific and Technical Publishers (CN4, Appendix 1), as suggested by the Shanghai Municipal Education Commission (2018). In the case of Taiwan, we chose two sets of $10^{\text {th }}$ grade chemistry textbooks and experimental workbooks (TW1 and TW2, Appendix 1) which are widely used in Taiwan and were recommended by the National Academy for Educational Research (National Academy for Educational Research, 2018). In addition to Mainland China and Taiwan, Malaysia is a country that operates a complete Chinese educational system from primary school all the way through to college. The country has about $23 \%$ ethnic Chinese out of a total of 32.4 million citizens (Xia et al., 2018; Xu \& Xu, 2016). Independent Chinese Secondary Schools (ICSSs) are segregated into a separate branch using Mandarin Chinese as the main instructional language (Vivien, 2018). Official bodies supporting the Chinese educational system in Malaysia are the United Chinese School Committees' Association (UCSCA or Dong Zong), together with the United Chinese School Teachers' Association (UCSTA or Jiao Zong) (Dong, 2018). In this study, we chose the Malaysian upper secondary chemistry textbook and the associated experimental workbook which is published by the United Chinese School Committees' Association of Malaysia (MY, Appendix 1).

\section{METHODS}

All of the textbooks were examined page by page. Each representation of practical work was carefully collected and listed. The collection considered suggestions for practical work, descriptions of laboratory procedures, and sketches,

Table 3: Types of learning (inspired by Millar et al., 1998)

\begin{tabular}{ll}
\hline Type of learning & Illustration \\
\hline Operating a given experiment & Tasks ask either the student or teacher to perform a given experiment \\
Picture/sketch illustration & Picture or sketches showing any experiment or practical activity to illustrate fact(s) \\
Picture/sketch illustration on a laboratory technique & Picture or sketches to illustrate a laboratory technique or the proper use of an apparatus \\
Scientific investigation with an open approach & Tasks that ask students to conduct (potential) experiments with an (at least partially) open approach \\
\hline
\end{tabular}


or pictures showing examples of practical work. This led to an overall total sample of 508 representations from the seven selected sets of textbooks and experimental workbooks.

Analysis of the data was performed using qualitative analysis inspired by Mayring (2014) in a combination of inductive and deductive formation of categories. For the general rating grid, four categories (C1-C4) were identified: Type of learning, intended learning outcomes, inquiry level, and students' engagement. Each category was also subdivided into 3-5 sub-categories (Table 2). Table 2 was modified several times. The pilot trial analysis was performed until the final version sufficiently matched the data. Detailed rating schemes were developed that finally led to an inter-rater agreement of above $85 \%$ for the initial coding and above $95 \%$ with the second round of joint coding and negotiating the cases of disagreement.

The final analyzing instrument was inspired by Millar et al. (1998), who looked at practical work involving learning activities to prepare students for specific learning outcomes (Table 3). Later, Millar et al. (1999) explored the variety of practical work and came up with different intended learning outcomes which were used as the basis for developing the coding grid found in Table 4. Concerning the inquiry level, we selected the model by Banchi and Bell (2008). Then, we extended it by adding a category called "confirmatory learning without hypothesis" based on findings that the former four levels did not cover all of the cases in our sample (Table 5). To compare levels of students' engagement presented by practical work, we refer to Tiberghien et al. (2001) to explore how given tasks engage students in practical work (Table 6).

\section{FINDINGS}

\section{Overall References to Practical Work}

A total number of 508 representations related to practical work were collected from the seven selected sets of textbooks and associated experimental workbooks. The numerical breakdown

Table 4: Intended learning outcomes/objectives of practical work (inspired by Millar et al., 1999)

\begin{tabular}{ll}
\hline Intended learning outcomes & Explanation \\
\hline $\begin{array}{l}\text { Identify objects and learn a } \\
\text { laboratory technique }\end{array}$ & $\begin{array}{l}\text { Support students in identifying chemical } \\
\text { objects and understanding a laboratory } \\
\text { technique. }\end{array}$ \\
Learn fact(s) & $\begin{array}{l}\text { Support students in learning fact(s) at the } \\
\text { phenomenological level so that they are able } \\
\text { using them later for understanding. }\end{array}$ \\
& $\begin{array}{l}\text { Support students in relating two or more } \\
\text { observable facts to understand a certain } \\
\text { Learn concept }\end{array}$ \\
& from observations. \\
&
\end{tabular}

Learn a relationship

Learn a theory/model with reference to the sub-microscopic level

\section{Examples}

Filtration

Distillation

Decanting

The proper use of a burette/separating funnel/centrifuge

Pure water boils at $100^{\circ}$ reat standard atmospheric pressure

Color change during chemical reactions

Flame color test

Redox reactions, chemical bonds

Molar mass

Forces

Electrolysis

Oxidation and reduction of iron and its compounds

Collecting data and drawing a diagram showing the relationship between potassium nitrate solutions and temperature

The reaction speed of the alkali metals increasing with an increasing period in the periodic table of elements

Substances in distillations evaporating dependent on their evaporation temperatures

Solubility varying with temperature

Law of definite proportions

Law of conservation of mass

The model of chemical reactions as a rearrangement of atoms to form new groups

Table 5: Levels of scientific inquiry (inspired by Banchi and Bell, 2008)

\begin{tabular}{l} 
Inquiry level \\
\hline Confirmatory learning without \\
hypothesis \\
Confirmatory inquiry learning \\
Structured inquiry learning \\
Guided inquiry learning \\
Open inquiry learning
\end{tabular}

Support students' data collection and interpretation skills using a specific theory based on unobservable entities, and hence help students to develop their understanding of the theory and how it can be applied.

\section{Explanation}

Learner given information or procedure without hypothesis, for example, laboratory technique operation manual

Verification/confirmatory activities providing a question and detailed instructions to get a result explained in the text Activities that provide a question and detailed instructions, but students have to find the answer Activities that provide a question and the students have to design their own method to find the answer

Activities that start from a fact or claim and students have to come up with a question, then design the method to find the answer 
of the representations was as follows: 98 from $\mathrm{CN} 1,75$ from $\mathrm{CN} 2,70$ from $\mathrm{CN} 3,61$ from $\mathrm{CN} 4,43$ from TW1, 45 from TW2, and 116 from MY.

Table 6: Students' engagement in practical activities (inspired by Tiberghien et al., 2001)

$$
\text { Context }
$$

Application
Detailed operation process

Picture/sketch aiding learning

Chemical equation writing

Safety operation tips

Chemical recycle and waste disposal

Sub-micro level explanation

Hands-on

Hands-free

Apply finding in a new context

\section{Type of Learning}

In the category labeled "type of learning," we can observe a wide variety (Figure 1). Figure 1 indicates that most of the practical work representations used in Mainland China and Malaysia focused on operating a given experiment. The Taiwanese textbooks had the lowest number of references to practical work. These were primarily pictures or sketches of experiments, either for illustration purposes or for introducing laboratory techniques. A scientific investigation employing at least a partially open approach could only be found in the textbooks from China and Malaysia to a varying degree. There were a total of 5 from CN4 and 23 in CN1. This was out of 61 to 98 representations of practical work in total, with having the highest numbers in $\mathrm{CN} 1$ and $\mathrm{CN} 2$ (23 and 17), correspondingly. Most of these were, however, taken from the

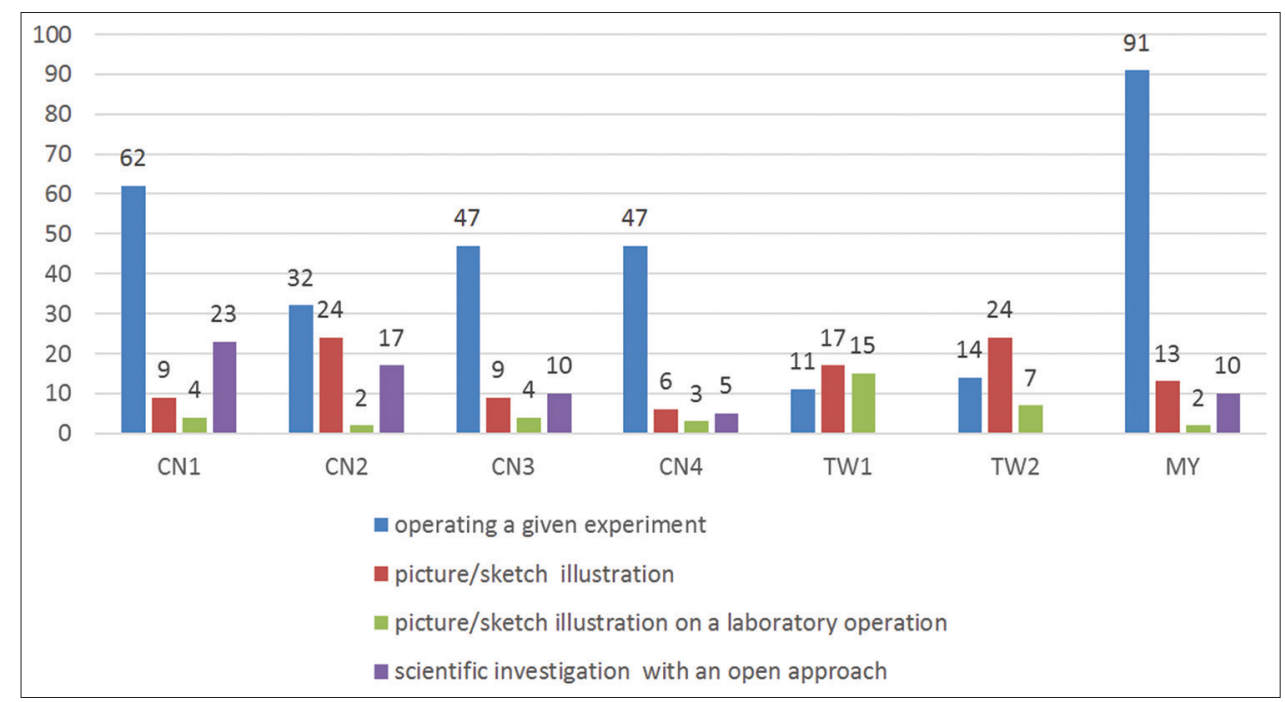

Figure 1: Type of learning suggested in presentations of practical work

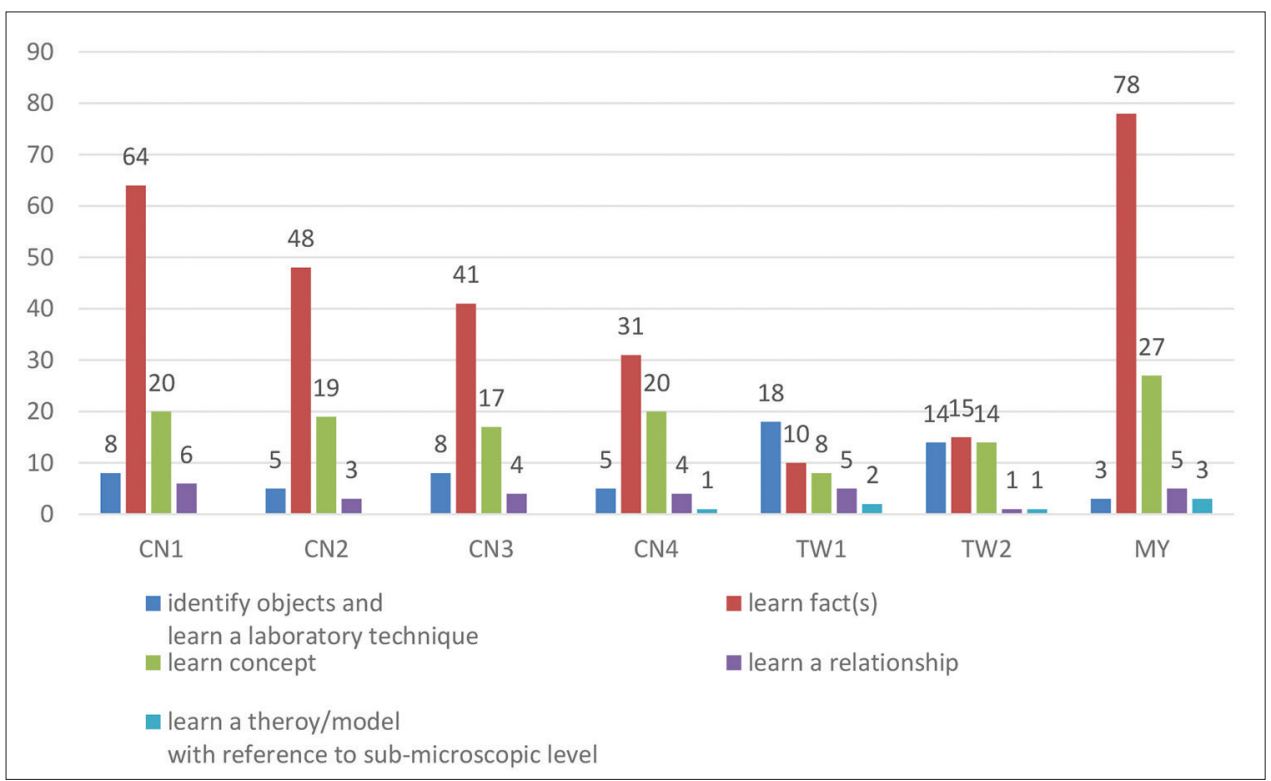

Figure 2: Intended learning outcomes suggested in presentations of practical work 
associated experimental workbooks, not from the textbooks themselves.

\section{Intended Learning Outcomes}

In terms of intended learning outcomes related to representations of practical work, we found a trend of "learning fact(s)" (Figure 2), which was quite pronounced in the textbooks taken from Mainland China and Malaysia $(\mathrm{CN} 1, \mathrm{CN} 2, \mathrm{CN} 3, \mathrm{CN} 4$, and $\mathrm{MY}$ ). In the textbooks from Taiwan, which had lower numbers of figures in total, this category was not so predominant. The learning of a concept category made up roughly $20-30 \%$ of the representations of practical work found in all the books. The use of practical work for learning relationships between factors and concepts tended to be $10 \%$ or less in all the textbooks. Learning about theories or models was only connected to practical work in 7 out of the 508 representations identified in the whole sample, thereby only hovering around the $1 \%$ mark.

\section{Inquiry Level of Practical Work}

Looking more closely at the data concerning levels of inquiry, we can see that textbooks from Mainland China and Malaysia tended to suggest more inquiry-based activities. Most examples consisted of structured inquiry learning, although a certain proportion also suggested guided inquiry learning approaches (Figure 3). Confirmatory inquiry learning appeared in all of the above-mentioned textbooks, with the Shanghai textbook (CN4) containing the smallest number (7) of examples. In the textbooks from Taiwan, confirmatory inquiry learning dominated suggestions for structured or guided inquiry learning, making up about $75 \%$ of the references to practical work. This proportion was much smaller in the textbooks taken from Mainland China and Taiwan, which had roughly $15-30 \%$ as many references, correspondingly. The Taiwanese textbooks referred more often to practical work with the use

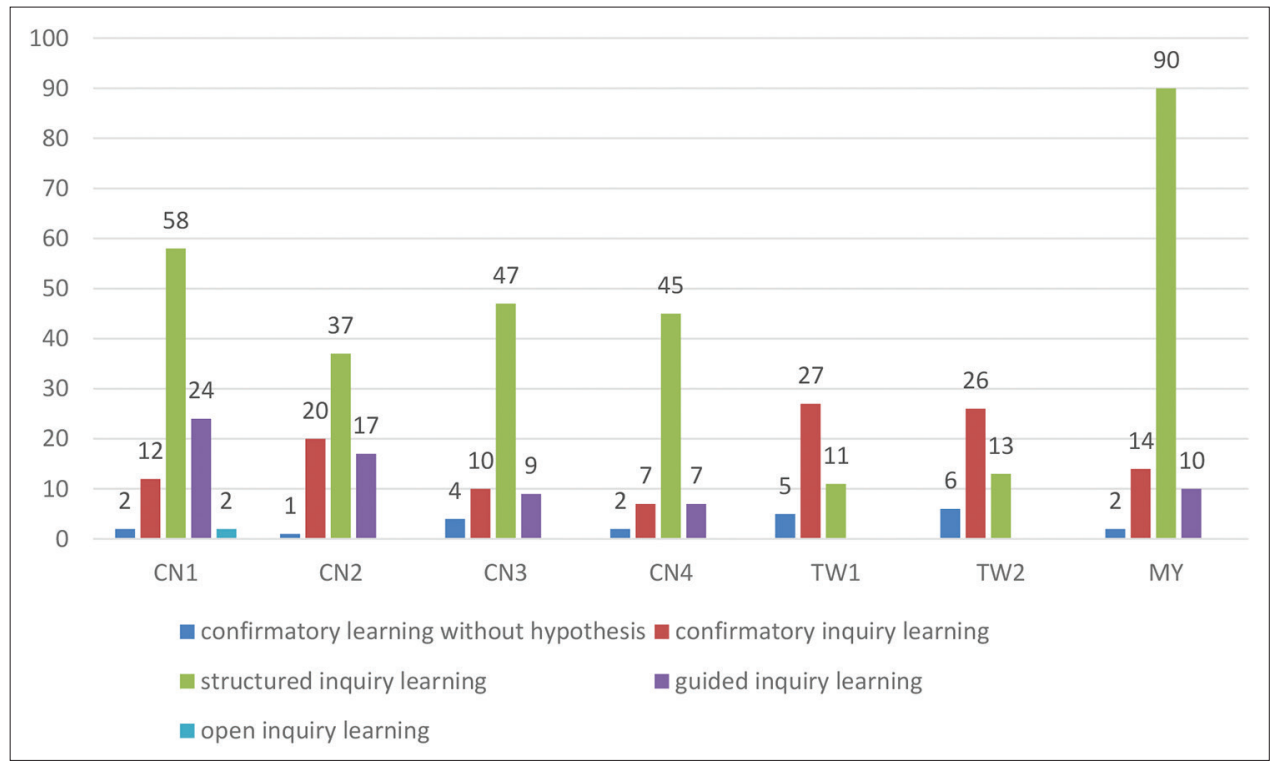

Figure 3: Inquiry level suggested in presentations of practical work

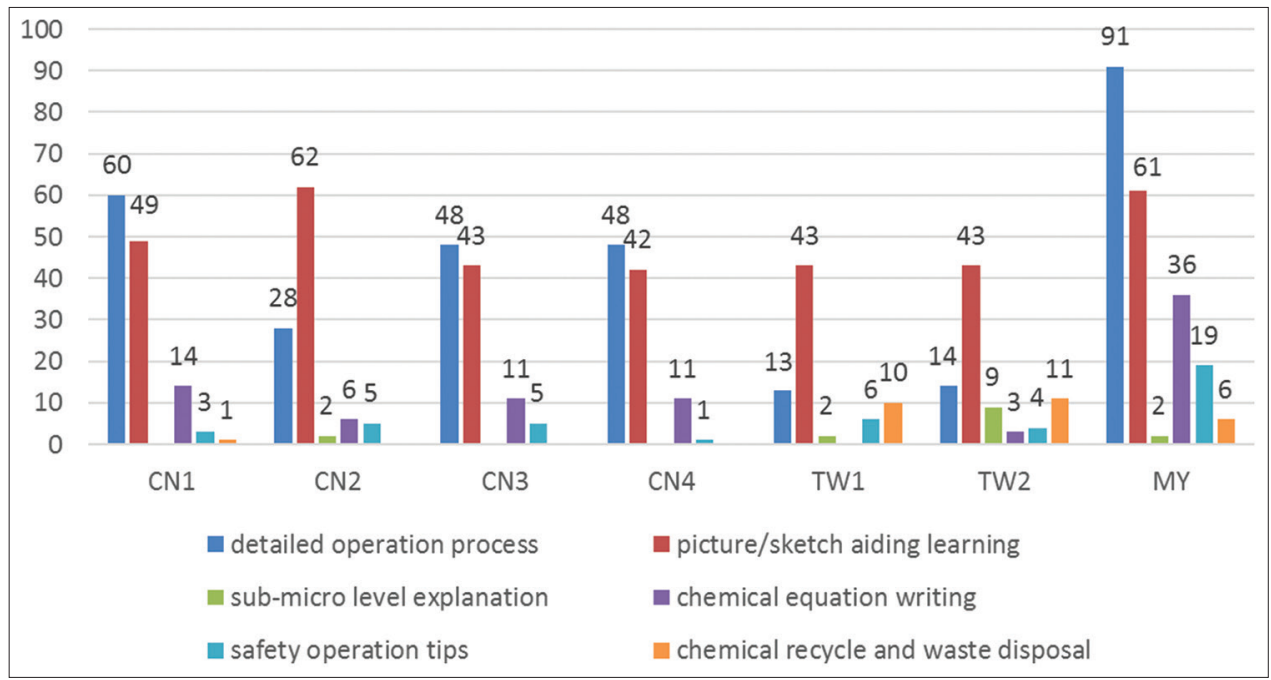

Figure 4: Students' engagement: Context related to presentations of practical work 


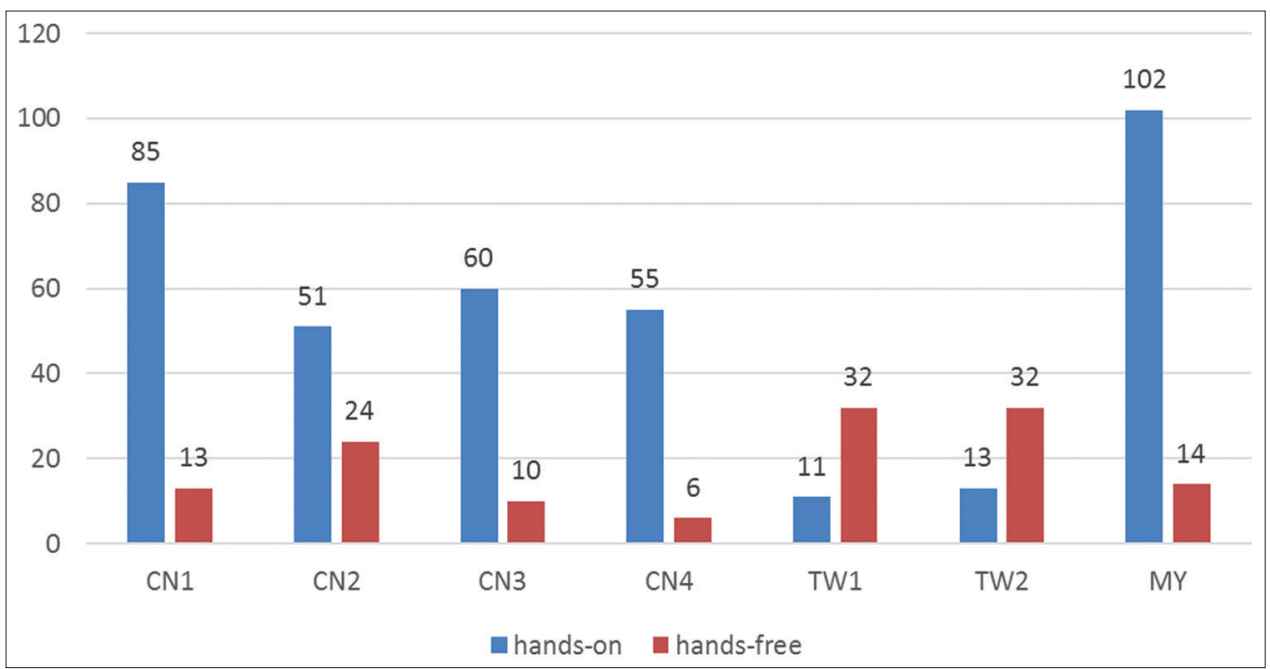

Figure 5: Students' engagement: Performance related to presentations of practical work

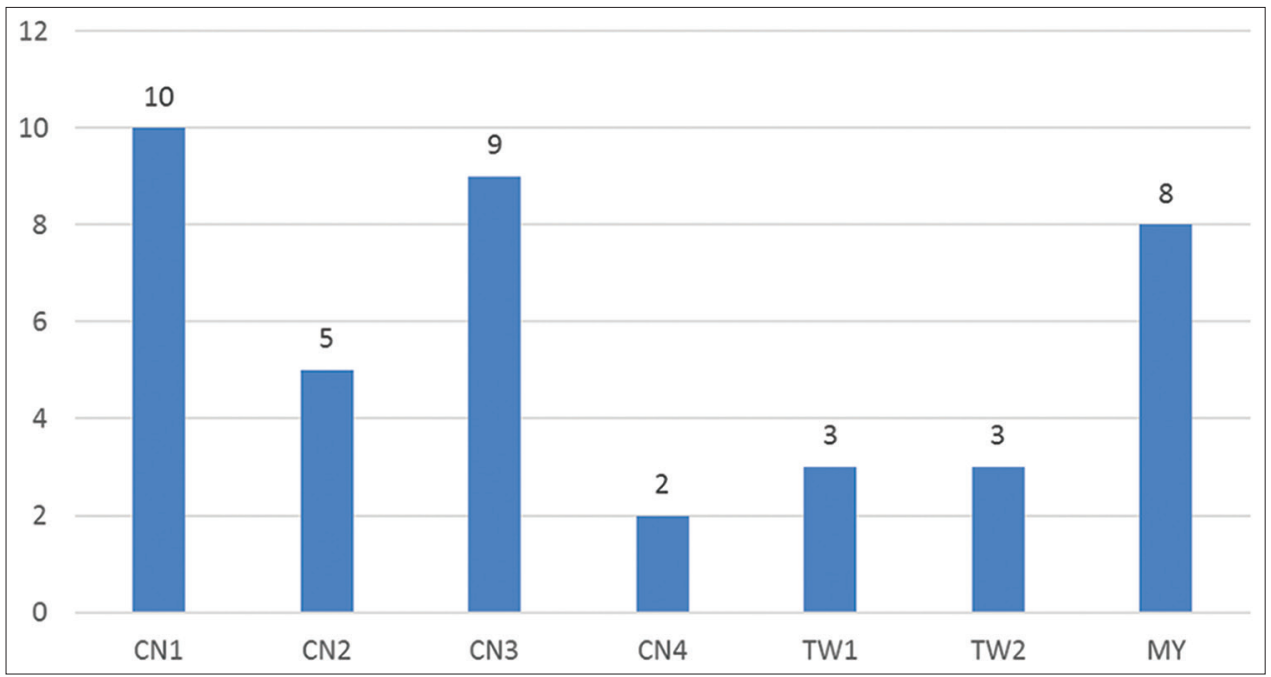

Figure 6: Students' engagement: Application of practical work to a new task

of pictures and sketches to illustrate the observation level. Confirmatory learning without a hypothesis tended to refer to the proper use of apparatus and essential operational processes such as filtration, distillation, and so on. There were, however, two suggested activities related to an open approach in one of the Mainland China textbooks (CN1). These were presented in an optional module in the experimental workbook.

\section{Students' Engagement with Practical Work}

The level of students' engagement with practical work varied widely in the different textbooks, as was the case in the other focuses of this study (Figure 4). In the textbooks from Mainland China and Malaysia, most references to practical work started with detailed instructions or using pictures or sketches to support learning. The highest number of detailed instructions could be found in the textbook from Malaysia. In Taiwan, there were much fewer detailed instructions; pictures and sketches to support learning dominate. All of the other categories played only a minor role. A focus on chemical recycling and waste disposal played a prominent role in the textbooks selected for Taiwan, making up roughly $25 \%$ of the references to practical work in both of the textbooks. It was also notable that hands-on activities were more often explicitly suggested in the textbooks from Mainland China and Malaysia than in the textbooks from Taiwan (Figure 5). Figure 6 shows that all of the textbooks provided references to practical work, asking students in certain situations to apply their findings in a new context. One example is that after students learn about the zinc-copper galvanic cell, extra tasks are given to them, which demand that they build a fruit battery with a tomato or a lemon. This is the case to a varying degree in only two or three up to ten tasks total (Figure 6).

\section{DISCUSSION AND CONCLUSIONS}

The purpose of this study was to examine Chinese $10^{\text {th }}$ grade chemistry textbooks and their associated experimental workbooks. We examined representations of practical work taken from 
Mainland China, Taiwan, and the Chinese sector in Malaysia. The study concentrated on the textbook analysis in four domains: Type of learning, intended learning outcomes, inquiry level, and aspects of students' engagement. There were similarities and differences in the chemistry textbooks of this sample. There were larger differences occurring in textbooks between different Chinese communities than within them. This could also be seen when we compared the use of visual representations in Chinese communities in the specific case of redox reaction content (Chen et al., 2019). The textbooks from Malaysia showed similar characteristics to those selected from Mainland China. This is in no way astonishing since educators from Mainland China take part in Malaysian ICSS chemistry textbook editing. The textbooks from Taiwan looked different in terms of the lower overall number of references to practical work, less representations of higher levels of inquiry learning, and in the number of references giving detailed instructions on how to carry out practical work.

In general, practical work in the textbooks from this sample refers to operating given experiments in all textbooks, except for Taiwan. In Taiwanese textbooks, more picture/sketch illustrations were used at the observational level. Confirmatory inquiry learning was quite dominant in Taiwanese textbooks, since they contained the highest proportion of picture/sketch resources that referred to corresponding tasks. This means that students observe pictures, instead of carrying out the whole experimental process for themselves. The other textbooks we examined tended to direct teachers and students more thoroughly toward a structured learning approach, which leads to an open answer for students to find by themselves. Guided inquiry learning could be found in all of the textbooks, except for Taiwan, but open inquiry learning only appeared as an optional module in one of the textbooks (CN1).

It is widely believed (Chiappetta \& Fillman, 2007) that textbooks represent publishers' and authors' choices on reflecting the nature of science. It has been suggested that if laboratory activities in textbooks are properly developed, they have the potential to develop both students' meaningful learning and their conceptual understanding. There is a gap in research in many countries to know exactly how teachers are using textbooks, both in terms of intensity and their pedagogical approach. It is suggested, however, that in many centralized educational systems, such as in Mainland China, curricula, and textbooks are officially reviewed and published to serve as the main educational resource for the teachers (Zhang \& Gao, 2013). In these countries, teachers rely heavily on the official curriculum, the associated textbooks, and any available teacher guidebooks when conducting their lessons. This was reported by Aldahmash et al. (2016) in the Saudi-Arabian context, where $100 \%$ of the teachers uniformly follow the same textbook in school step by step. Their data showed that this close adherence to the textbook led to a quite teacher-centered pedagogy. Similar claims that teachers are closely following the curriculum and textbook have also been made in the case of Mainland China (Wang, 2010). Reasons for this include the fact that a given educational system is a combination of physical settings (e.g., class size and class resource) and social settings (e.g., learners' background, local community, school principle, nation policy, and local education authority) (Watson et al., 2004). Another factor is the dominant role of centralized national college entrance exams in China, which focus more on rote learning of knowledge than on inquiry skills (Davey et al., 2007). This clear focus on final exams has already been described as a hindrance to educational reform toward more open teaching approaches (Chai \& Cheng, 2011). Similar claims might also be assumed for the Chinese sector in Malaysia. Peen and Arshad (2014) stated that in Malaysian secondary schools, students get used to relying on their teachers for all information and instructions. They mostly listen passively to the teachers with occasionally limited questions being asked. If the teacher follows the textbooks step by step, there is a clear line for how practical work is introduced by the textbook to how it, therefore, effects students.

In other countries, it might be possible to find more openness for teachers to combine textbooks use with other media, for example, worksheets or internet resources, if such media are available. Countries with higher average levels of socioeconomic development might expect their teachers to possess more resources than just the textbook, for example, digital media. Internet access should be available more broadly to enrich the learning experience in schools. Evidence has already shown that technology-aided learning in science education has become a popular trend in Taiwan (Lin \& Tsai, 2016) and was also introduced in secondary chemistry education (Chen, 2018). This might be one reason for the lower number of representations of hands-on practical work suggestions in the textbooks from Taiwan if the textbook is being combined with other resources. To answer whether this is the reason, however, further research would be needed on how teachers in Taiwan rely on the textbook for lesson planning. It also needs to research in which manner textbooks are being combined with other resources.

This study is limited to chemistry education in three Chinese communities and only looks at one certain grade level. It also only deals with one aspect of textbooks and cannot say how these textbooks are being used, either as stand-alone tools or in combination with other resources. Answering these questions opens up further possibilities for research in the future. It also can stimulate further research into how textbooks develop over time. Malaysia recently implemented new chemistry textbooks and Mainland China will do so in the near future. Thus, the analysis of textbooks presented here can only be a snapshot in time, which needs to be revisited and deepened after the next round of curriculum reform and its implementation take place.

\section{ACKNOWLEDGMENT}

We would like to thank the China Scholarship Council (CSC) and the program STIBET Doktoranden at the University of Bremen for funding this research. We appreciate cooperation in this research with Robin Millar (UK), Chua Kah Heng (Malaysia), and Hongseok Jeong (Korea). 


\section{REFERENCES}

Abd-El-Khalick, F., Waters, M., \& Le, A.P. (2008). Representations of nature of science in high school chemistry textbooks over the past four decades. Journal of Research in Science Teaching, 45(7), 835-855.

Abrahams, I., \& Millar, R. (2008). Does practical work really work? A study of the effectiveness of practical work as a teaching and learning method in school science. International Journal of Science Education, 30(14), 1945-1969.

Abrahams, I., \& Reiss, M.J. (2012). Practical work: Its effectiveness in primary and secondary schools in England. Journal of Research in Science Teaching, 49(8), 1035-1055.

Aldahmash, A.H., Mansour, N.S., Alshamrani, S.M., \& Almohi, S. (2016). An analysis of activities in Saudi Arabian middle school science textbooks and workbooks for the inclusion of essential features of inquiry. Research in Science Education, 46(6), 879-900.

Banchi, H., \& Bell, R. (2008). The many levels of inquiry. Science and Children, 46(2), 26-29.

Chai, C., \& Cheng, G. (2011). Policies on China's basic education over the last thirty years. In: Zhang, X. (Ed.), China's Education Development and Policy, 1978-2008. Leiden: Brill. p111-163.

Chen, X., Goes, L.F., Treagust, D.F., \& Eilks, I. (2019). An analysis of the visual representation of redox reactions in secondary chemistry textbooks from different Chinese communities. Education Sciences, $9(1), 42$.

Chen, Z.S. (2018). Application of software and platform in primary and secondary chemistry teaching-promote the acid-base conceptual learning by creating an educational platform. Chemistry Education in Taiwan, 24, 1-7.

Chiappetta, E.L., \& Fillman, D.A. (2007). Analysis of five high school biology textbooks used in the United States for inclusion of the nature of science. International Journal of Science Education, 29(15), 1847-1868.

Clement, P. (Ed.). (2008). Special issue of SEI-relating to critical analysis of school science textbooks. Science Education International, 19(2), 98-250.

Davey, G., Lian, C.D., \& Higgins, L. (2007). The university entrance examination system in China. Journal of Further and Higher Education, 31(4), 385-396.

Devetak, I., \& Vogrinc, J. (2013). The criteria for evaluating the quality of the science textbooks. In: Khine, M. (Ed.), Critical Analysis of Science Textbooks. Dordrecht: Springer. p3-15.

Dong, Z. (2018). The Background of Dong Zong's Establishment. Available from: http://www.dongzong.my/eindex.php. [Last accessed on 2019 Feb 09].

Hofstein, A. (2017). The role of laboratory in science teaching and learning. In: Taber, K.S., \& Akpan, B. (Eds.), Science Education. Rotterdam: Sense. p357-368.

Hofstein, A., \& Lunetta, V.N. (1982). The role of the laboratory in science teaching: Neglected aspects of research. Review of Educational Research, 52(2), 201-217.

Hofstein, A., \& Lunetta, V.N. (2004). The laboratory in science education: Foundations for the twenty-first century. Science Education, 88(1), 28-54.

Jones, M.E., Gott, R., \& Jarman, R. (2000). Investigations as part of the key stage 4 science curriculum in Northern Ireland. Evaluation and Research in Education, 14(1), 23-37.

Katchevich, D., Hofstein, A., \& Mamlok-Naaman, R. (2013). Argumentation in the chemistry laboratory: Inquiry and confirmatory experiments. Research in Science Education, 43(1), 317-345.

Khaddoor, R., Al-Amoush, S., \& Eilks, I. (2017). A comparative analysis of the intended curriculum and its presentation in $10^{\text {th }}$ grade chemistry textbooks from seven Arabic countries. Chemistry Education Research and Practice, 18(2), 375-385.

Kim, H., \& Song, J. (2006). The features of peer argumentation in middle school students' scientific inquiry. Research in Science Education, 36(3), 211-233.

Kim, H.T., \& Kim J.G. (2013). How do high school textbooks in Korea, Japan and the U.S. explain bioaccumulation concepts? Science Education International, 24(4), 416-436.

Lederman, N.G., \& Lederman, J.S. (2012). Nature of scientific knowledge and scientific inquiry: Building instructional capacity through professional development. In: Fraser, B., Tobin, K., \& McRobbie, C. (Eds.), Second
International Handbook of Science Education. Dordrecht: Springer. p335-359.

Lin, T.C., \& Tsai, C.C. (2016). Innovative technology-assisted science learning in Taiwan. In: Chiu, M.H. (Ed.), Science Education Research and Practice in Asia. Singapore: Springer. p189-209.

Mayring, P. (2014). Qualitative Content Analysis. Available from: http:/ www.psychopen.eu/fileadmin/user upload/books/mayring/ssoar-2014mayring Qualitative_content_analysis_theoretical_foundation.pdf. [Last accessed on 2019 May 22].

Millar, R. (2004). The Role of Practical Work in the Teaching and Learning of Science. Paper Prepared for the Meeting High School Science Laboratories: Role and Vision. Washington, DC: National Academy of Sciences.

Millar, R., Le Maréchal, J.F., \& Tiberghien, A. (1998). A Map of the Variety of Labwork. Available from: http://www.epitropakisg.gr/grigorise/ Labwork-wp1.pdf. [Last accessed on 2019 May 13].

Millar, R., Le Maréchal, J.F., \& Tiberghien, A. (1999). "Mapping" the domain: Varieties of practical work. In: Leach, J., \& Paulsen, A.C. (Eds.), Practical Work in Science Education: Recent Research Studies. Dordrecht: Kluwer. p33-59.

Ministry of Education. (2003). National Upper Secondary School Chemistry Curriculum Standards. Beijing: People's Education Press.

Ministry of Education. (2017). National upper secondary school chemistry curriculum standards. Beijing: People's Education Press.

Ministry of Education. (2018). Notice of the Teaching Books for Primary and Secondary Schools in 2018. Available from: http://www.moe.gov.cn/ srcsite/A26/moe 714/201805/t20180507 335240.html. [Last accessed on 2019 May 20].

National Academy for Educational Research. (2018). Textbooks for Upper Secondary School. Available from: http://www.review.naer.edu.tw/ Bulletin/PA02.php. [Last accessed on 2019 Feb 08].

Newton, P., Driver, R., \& Osborne, J. (1999). The place of argumentation in the pedagogy of school science. International Journal of Science Education, 21(5), 553-576.

Peen, T.Y., \& Arshad, M.Y. (2014). Teacher and student questions: A case study in Malaysian secondary school problem-based learning. Asian Social Science, 10(4). 174-182.

Rusek, M., \& Vojiřr, K. (2019). Analysis of text difficulty in lower-secondary chemistry textbooks. Chemistry Education Research and Practice, 20(1), 85-94.

Shanghai Municipal Education Commission. (2018). Announcement of Recommendation for Primary and Secondary Textbooks for 2019 Academic Year. Available from: http://www.shmec.gov.cn/html/ xxgk/201811/402052018009.html. [Last accessed on 2019 Mar 05].

Stern, L., \& Roseman, J.E. (2004). Can middle-school science textbooks help students learn important ideas? Findings from Project 2061's curriculum evaluation study: Life science. Journal of Research in Science Teaching, 41(6), 538-568.

Sun, Y., Xu, D., Zhang, F., \& Zhao, C. (2016). 25 Years of Curriculum Reform in Shanghai. (上海课程改革25年). China: Shanghai Educational Publishing House.

Tamir, P., \& Pilar-Garcia, M. (1992). Characteristics of laboratory exercises included in science textbooks in Catalonia (Spain). International Journal of Science Education, 14(4), 381-392.

Tiberghien, A., Veillard, L., Le Maréchal, J.F., Buty, C., \& Millar, R. (2001). An analysis of labwork tasks used in science teaching at upper secondary school and university levels in several European countries. Science Education, 85(5), 483-508.

Upahi, J.E., \& Ramnarain, U. (2019). Representations of chemical phenomena in secondary school chemistry textbooks. Chemistry Education Research and Practice, 20(1), 146-159.

Vivien, W. (2018). The language medium policies: A study on the development of independent Chinese secondary schools (ICSS) in Malaysia. KATHA The Official Journal of the Centre for Civilisational Dialogue, 13(1), 32-53.

Wang, L. (2010). Basic chemistry education curriculum reform progress and reflection in the past years (Volume I). Chinese Journal of Chemical Education, 31(4), 15-21.

Wang, L., Tang, J., Zhang, R., Hu, J., Zhi, Y., \& Wei, R. (2015). Investigation of the use of new chemistry textbooks of senior high school and the 
influential factors. Journal of Educational Studies, 11(4), 77-86.

Watson, R.J., Swain, J.R.L., \& McRobbie, C. (2004). Students' discussions in practical scientific inquiries. International Journal of Science Education, 26(1), 25-45.

Wei, B., \& Chen, B. (2017). Examining the senior secondary school chemistry curriculum in China in view of scientific literacy. In: Liang, L., Liu, X., \& Fulmer, G. (Eds.), Chinese Science Education in the 21 $1^{\text {st }}$ Century: Policy, Practice, and Research. Contemporary Trends and Issues in Science Education. Dordrecht: Springer. p133-148.
Xia, N., Yang, Y.N., \& Lee, Y.E. (2018). Chinese education in Malaysia under Malaysian ethnic politics. Journal of Politics and Law, 11(2), 23-36.

Xu, L.L., \& Xu, P. (2016). The Popularization of Chinese Language in Multilingual Environment based on the Analysis of Examples from Malaysia. Paper Presented at the $2^{\text {nd }}$ International Conference on Modern Education and Social Science. MESS.

Zhang, H., \& Gao, Z. (2013). Curriculum studies in China: Retrospect and prospect. In: Pinar, W.F. (Ed.), International Handbook of Curriculum Research. $2^{\text {nd }}$ ed. New York: Routledge. p118-133.

\section{APPENDIX}

\begin{tabular}{|c|c|c|}
\hline \multicolumn{3}{|c|}{ Appendix 1: Overview of the textbooks } \\
\hline Textbook & References & Pages \\
\hline \multirow[t]{3}{*}{$\mathrm{CN1}$} & Song, X.Q. (Ed.). (2007). Chemistry 1. $3^{\text {rd }}$ ed. Beijing: People Education Press. & 111 \\
\hline & Song, X.Q. (Ed.). (2007). Chemistry 2. $3^{\text {rd }}$ ed. Beijing: People Education Press. & 112 \\
\hline & Song, X.Q. (Ed.). (2007). Chemistry Experiment. $4^{\text {rd }}$ ed.. Beijing: People Education Press. & 26 out of 81 \\
\hline \multirow[t]{3}{*}{$\mathrm{CN} 2$} & Wang, L. (Ed.). (2007). Chemistry 1. $3^{\text {rd }}$ ed. Shandong: Shandong Science and Technology Press. & 139 \\
\hline & Wang, L. (Ed.). (2007). Chemistry 2. $3^{\text {rd }}$ ed. Shandong: Shandong Science and Technology Press. & 103 \\
\hline & Wang, L. (Ed.). (2007). Chemistry Experiment. $2^{\text {nd }}$ ed. Shandong: Shandong Science and Technology Press. & 39 out of 126 \\
\hline \multirow[t]{3}{*}{$\mathrm{CN} 3$} & Wang, Z.H. (2014). Chemistry 1. $6^{\text {th }}$ ed. Nanjing: Jiangsu Education Press. & 111 \\
\hline & Wang, Z.H. (2015). Chemistry 2. $6^{\text {th }}$ ed. Nanjing: Jiangsu Education Press. & 109 \\
\hline & Wang, Z.H. (2009). Chemistry Experiment. $2^{\text {nd }}$ ed. Nanjing: Jiangsu Education Press. & 36 out of 106 \\
\hline \multirow[t]{4}{*}{$\mathrm{CN} 4$} & Yao, Z.P. (Ed.). (2007). Chemistry. $1^{\text {st }}$ ed., Vol. 1. Shanghai: Shanghai Scientific and Technical Publishers. & 99 \\
\hline & 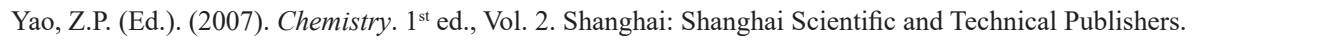 & 86 \\
\hline & Yao, Z.P. (Ed.). (2007). Chemistry Workbook. $1^{\text {st }}$ ed., Vol. 1. Shanghai: Shanghai Scientific and Technical Publishers. & 4 out of 40 \\
\hline & Yao, Z.P. (Ed.). (2007). Chemistry Workbook. 1 ${ }^{\text {st }}$ ed., Vol. 2. Shanghai: Shanghai Scientific and Technical Publishers. & 10 out of 49 \\
\hline \multirow[t]{2}{*}{ TW1 } & Huang, D.S. (Ed.). (2010). Basic Chemistry 1. $1^{\text {st }}$ ed. Taiwan: LungTeng Cultural Co., Ltd. & 189 \\
\hline & Huang, D.S. (Ed.). (2010). Basic Chemistry 1-Experimental Manuscript. $1^{\text {st }}$ ed. Taiwan: Lungteng Cultural Co., Ltd. & 77 \\
\hline \multirow[t]{2}{*}{ TW2 } & Yeh, M.C.P. (Ed.). (2010). Basic Chemistry 1. $1^{\text {st }}$ ed. Taiwan: Nan I Book Enterprise. & 192 \\
\hline & Yeh, M.C.P. (Ed.). (2011). Basic Chemistry 1-Experimental Manuscript. 1 ${ }^{\text {st }}$ ed. Taiwan: Nan I Book Enterprise. & 47 \\
\hline \multirow[t]{2}{*}{ MY } & $\begin{array}{l}\text { Wang, C.K. (2017). Upper Secondary School Chemistry. 1 }{ }^{\text {st }} \text { ed., Vol. 1. Malaysia: United Chinese School Committees' } \\
\text { Association of Malaysia. }\end{array}$ & 447 \\
\hline & $\begin{array}{l}\text { Wang, C.K., \& Lin, Y. (2018). Chemistry Experiment Manuscript. } 1^{\text {st }} \text { ed., Vol. 1. Malaysia: United Chinese School } \\
\text { Committees' Association of Malaysia. }\end{array}$ & 126 \\
\hline
\end{tabular}

